\title{
The Preparation of Dye-Acrylamide/Itaconic Acid Gel Dosimeters for Process Validation of Medical Device Sterilization
}

\author{
Tıbbi Cihazların Sterilizasyonunun Proses Validasyonu için Hazırlanan \\ Boya-Akrilamid/Itakonik Asit Jel Dozimetresi
}

\author{
(D) Betül TAŞDELEN, (D) Sarkis SÖZKES \\ Tekirdağ Namık Kemal University, Çorlu Faculty of Engineering, Department of Biomedical Engineering, Tekirdağ, Turkey
}

\begin{abstract}
Aim: In this study, a new polymer gel dosimeter (PGD) was prepared using gamma rays for process validation of medical device sterilization. New polymeric systems were studied, consisting of itaconic acid, acrylamide, gelatin, different dyes [methylene blue, methyl orange and crystal violet (CV)] and N,N'-methylenebisacrylamide, with ascorbic acid as an oxygen scavenger.

Materials and Methods: The study investigated the effect of the different dyes in the newly prepared PGD dosimeter formulations on the dose rate constants and radiation chemical yields in the high dosage ranging from 7 to $28 \mathrm{kGy}$-typical for the sterilization of many medical devices, pharmaceutical products and biological tissue-by using a ultraviolet-visible spectrophotometer method.

Results: The sample spectrums of the prepared PGD dosimeters underwent a change following gamma irradiation, and bleaching of the blue gel color increased with the radiation dose. Even at the sterilization dose for medical devices ( $25 \mathrm{kGy})$, the dark blue color of the non-irradiated CVPGD became almost colorless. The response of non-irradiated and irradiated PGD dosimeters remained stable during a storage period of 60 days.

Conclusion: The prepared dye-PGD dosimeters are therefore suitable for use in monitoring various high dose radiation-processing applications, which can be useful for many medical devices and healthcare products.
\end{abstract}

Keywords: Dosimeter, gamma ray, radiation, sterilization

ÖZ

Amaç: Bu çalışmada tıbbi cihazların sterilizasyonunun proses validasyonu için kullanılacak yeni bir polimer jel dozimetre (PGD), gama ışınları kullanılarak hazırlanmıştır. İtakonik asit, akrilamid, jelatin, farklı boyalar [metilen mavisi, metil turuncusu ve kristal mor (KM)] ve oksijen tutucu olarak N, N'-metilenbisakrilamid ve askorbik asitten oluşan yeni polimerik sistemler üzerinde çalışılmıştır.

Gereç ve Yöntem: Hazırlanan yeni PGD dozimetre formülasyonlarındaki farklı boyaların doz hız sabitleri ve radyasyon kimyasal verimleri üzerindeki etkisi, birçok tıbbi cihaz, farmasötik ürün ve biyolojik dokunun ultraviyole kullanılarak sterilizasyonu için tipik olan 7-28 kGy yüksek doz aralığında spektrofotometre yöntemi ile araştırılmıştır.

Bulgular: Hazırlanan PGD dozimetrelerinin spektrumu, numunelerin gama ışıması üzerine bir değişikliğe uğraması ve mavi jel renginin ağartılması, radyasyon dozu ile artar; tıbbi cihazın sterilizasyon dozunda (25 kGy) bile, ışınlanmamış KM-PGD'nin koyu mavi rengi neredeyse renksiz olana dönmüştür. Işınlanmamış ve ışınlanmış PGD dozimetrelerinin tepkisi, 60 günlük saklama süresi boyunca oldukça kararlıdır.

Sonuç: Hazırlanan boya-PGD dozimetrelerinin yüksek doz gerektiren radyasyon proses uygulamalarında, örneğin; tıbbi cihazlar ve sağlık bakım ürünlerinin sterilizasyonunun proses validasyonunda faydalı olacağı kanaatindeyiz.

Anahtar Kelimeler: Dozimetre, gama ışını, ışınlama, sterilizasyon

Address for Correspondence: Sarkis SÖZKES MD, Tekirdağ Namık Kemal University, Çorlu Faculty of Engineering, Department of Biomedical Engineering, Tekirdağ, Turkey Phone: +90 2822502347 E-mail: ssozkes@nku.edu.tr ORCID ID: orcid.org/0000-0003-1555-3591

Received: 27.10.2020 Accepted: 23.12.2020

๑Copyright 2021 by the Tekirdağ Namık Kemal University Faculty of Medicine / Namık Kemal Medical Journal published by Galenos Publishing House. 


\section{INTRODUCTION}

In the medical sector, process validation of medical device sterilization is crucial. Unfortunately, surgical devices are not properly sterilized in many places across the world. Many patients die or are diagnosed with various infections after surgery because of improper sterilization.

Authorities require regular sterilization as a mandatory process for the most of the medical equipments and devices'. Sterilization is a process that ensures the medical device is without bacteria and any microorganisms. Medical devices are mostly reused for other patients after surgical operations, where they are contaminated by microorganisms. Therefore, effective sterilization is necessary in order to reuse such medical devices again. Ethylene oxide (ETO) sterilization, autoclaving as steam sterilization, radiation, hydrogen peroxide sterilization and chlorine dioxide sterilization are various methods of sterilization ${ }^{1,2}$. To sterilize the medical devices such as syringes, implants, medical dressings, bloodbags and artificial joints methods such as gamma radiation from cobalt-60 $\left({ }^{60} \mathrm{Co}\right), \mathrm{X}$-rays or electron beams were used for many years. Sterilization of homogeneous systems and heterogeneous systems such as solid materials, gas materials, liquid materials and also medical devices are done gamma rays $^{3}$. Gamma irradiation has physical inhibation effect on bacterial division by breaking the DNA of bacteria for providing decontamination to kill bacteria ${ }^{4}$. Contamination is caused by the energy of gamma rays passing through the equipments which disrupts pathogens. The reproduction capability or life of organisims causing contamination is finished by molecular changes induced by photons. Irradiation by gamma creates no radioactivity for medical equipment. Comparing with other methods of sterilisation gamma irradiation have reasons for preferance. Comparing with aseptic process method and filtration method, no excess ETO residues, advantage of less temperature for processing and easy validation of the sterilisation can be counted as the advantages of gamma irradiation ${ }^{5}$.

Eventhough dose is accepted as sterilisation standard parameter for validation of the sterilisation of medical equipment,to measure the dose is not an easy task. If the reponse to the dose of radiation is known and can be reproducibly achieved, then small blocks made of plastic, films, pellets or fluids may be used as dosimeters 6 .

Polymer gel dosimeters (PGD) are prepared from radiationsensitive chemicals. These chemicals polymerize depending on the absorbed radiation dose $\mathrm{e}^{7-10}$. These gel dosimeters do not have recording limitations and maintain distribution in threedimensions. They also have specific advantages when compared to one-dimensional dosimeters, such as ion chambers, and two-dimensional dosimeters, such as film.
Different PGD compositions and monomers in different types were studied. The aim was to create dosimetry system with temporal stability, spatial stability, dose-response exhibition in an optimal level, dose rate dependency and energy rate dependency for suitable and easy applications in clinic ${ }^{11-13}$.

Tetrakis phosphonium chloride (THPC) or an oxygen inhibiter like ascorbic acid is homogenously used in these systems as an agent for crosslinking in an aqueous gel matrix. The changes in the physical properties of the material is produced by the reactions of crosslinking agents and monomers to initiate the polymerization and gel form from water radiolysis the formation of free radicals which are induced by ionizing radiation.

In this study, a new polymeric system consisting of itaconic acid $(\text { ITA })^{14}$, acrylamide (AAm), gelatin, different dyes [methylene blue (MB), methyl orange (MO) and crystal violet (CV)] and $\mathrm{N}, \mathrm{N}^{\prime}$-methylenebisacrylamide (BIS), with ascorbic acid as an oxygen scavenger was studied. The use of doses from 0 to $1000 \mathrm{~Gy}$ have been already studied for hydrogel formation with the monomers ITA and BIS in an aqueous gelatin solution with THPC as an oxygen scavenger ${ }^{15}$. The effects of the different dyes in the newly prepared PGD dosimeter formulations were investigated in a high dose range from 7 to $28 \mathrm{kGy}$, typical for syringe sterilization, using a ultraviolet (UV)-visible spectrophotometer method.

\section{MATERIALS AND METHODS}

\section{Materials}

AAm (99\%), ITA (99\%), BIS, ascorbic acid, MO and CV were obtained from the Sigma Aldrich Chemical Company. MB was supplied by Merck (cat no: 1,05045,0100). All the reagents mentioned above were used as received.

\section{Method}

All applicable international and national ethical guidelines were followed. No animal or human subject requiring ethics committee approval was included in the study. The optical absorbency of all irradiated samples was measured by a Shimadzu UV-visible spectrophotometer (Shimadzu UV2401). The absorbencies of the PGDs were determined to be at wavelengths of 592, 664 and $462 \mathrm{~nm}$ before and 24 hours after their irradiation. These have been given as the ideal stabilization duration of the polymerization reactions within a PGD ${ }^{16}$. The optical absorbance of the irradiated sample (Ai) and its sample non-irradiated correspondence(Ao) difference is defined as Relative absorbance $(\Delta A)$. Then, $\Delta A$ fits to a linear function of the dose (D), and PGD sensitivity is represented by the slope(s) ${ }^{12}$.

$\Delta A: A i-A o=s D+n$

Equation (1) 
The $\mathrm{pH}$ was measured using a $\mathrm{pH}$ meter (WTW $\mathrm{pH}$ 315i). The chemical characteristics of the PGD dosimeters were characterized using fourier transform infrared spectroscopy (Bruker VERTEX 70 ATR).

\section{Preparation of the Polymer Gel Dosimeters}

AAm-based gels were prepared based on the Venning method ${ }^{16}$ using $89 \% \mathrm{w} / \mathrm{w}$ of ultrapure deionized water, $5 \% \mathrm{w} / \mathrm{w}$ of gelatin, $3 \% \mathrm{w} / \mathrm{w}$ of BIS, $3 \% \mathrm{w} / \mathrm{w}$ of AAm, $1 \% \mathrm{w} / \mathrm{w}$ of ITA, $0.1 \%$ $\mathrm{w} / \mathrm{w}$ of three different dyes (MB, MO and CV) and $10 \mathrm{mM}$ of ascorbic acid. The gelatin was mixed with $90 \%$ of the water in dosimeters for a duration of ten minutes at room temperature. Then, the temperature was set to $45^{\circ} \mathrm{C}$ and constantly stirred to obtain the homogeneousity of the solution. Afterwards, BIS was added to the solution and mixed for 15 minutes at $45^{\circ} \mathrm{C}$. After that, the temperature was decreased to $37{ }^{\circ} \mathrm{C}$ and the AAm, IA and MB were added. The total solution was mixed at $37{ }^{\circ} \mathrm{C}$ for 30 minutes and ascorbic acid was mixed with the remaining $10 \%$ of the water at $35{ }^{\circ} \mathrm{C}$. For two minutes the solution was kept in same condition. The prepared solutions were then put into glass tubes with stoppers ${ }^{17}$. For stabilization purposes, the dosimeters put in storage at $4{ }^{\circ} \mathrm{C}$ for 24 hours before irradiation. Irradiation of all solutions was performed with a Nordion-Canada model JS 9600 model gamma irradiator from Gamma-Pak Ind \& Trade Inc under air at $25^{\circ} \mathrm{C}$. The PGD dosimeters were irradiated up to the maximum $25 \mathrm{kGy}$ dose at a dose rate of $3 \mathrm{kGy} / \mathrm{h}$.

\section{Statistical Analysis}

Equation 2 may be used to express the dye removal with gamma irradiation ${ }^{18}$. The constant of dose, $k_{1}$ is the natural logarithm (In) of the slope of the compound concentration versus the absorbed dose.

$\ln (\mathrm{C} / \mathrm{C} 0)=\mathrm{kD}$

Equation (2)

where $C$ is the concentration after gamma irradiation (M), $C 0$ is the initial concentration (M), $\mathrm{k}$ is the dose constant $(\mathrm{Gy}-1)$ and $D$ is the absorbed dose (Gy).

Necessary doses for Degradation percentage $50 \%, 90 \%$ and $99 \%$ degradation of $\mathrm{CV}\left(\mathrm{D}_{0.5^{\prime}}, \mathrm{D}_{0.9}\right.$ and $\mathrm{D}_{0.99}$ values) constants were calculated by using equations 3,4 and 5 , respectively ${ }^{18}$.

$\mathrm{D}_{0.5}=\ln (2) / \mathrm{k}$

Equation (3)

$\mathrm{D}_{0.9}=\ln (10) / \mathrm{k}$

Equation (4)

$\mathrm{D}_{0.99}=\ln (100) / \mathrm{k}$

Equation (5)

Table 1 shows the calculated $k_{1}$ and the $\mathrm{D}_{0.5} \mathrm{D}_{0.9}$ and $\mathrm{D}_{0.99}$ values for the different dye-PGD dosimeters prepared.

Absorbtion of $100 \mathrm{eV}$ energy by degraded molecules is the definition of the $\mathrm{G}$ value ${ }^{19}$.

\section{RESULTS}

The $\mathrm{G}$ value was calculated using equation $6 .^{20}$

$\mathrm{G}=6.023 \times 10^{23} \Delta \mathrm{R} / 6.24 \times 10^{17} \mathrm{D}$

Equation (6)

where $D$ is the absorbed dose (Gy), the dye (M) concentration change is $\Delta R$, the factor of conversion from Gy to $100 \mathrm{eV} / \mathrm{L}$ is $6.24 \times 10^{16}$ and the constant of avogadro is $6.023 \times 10^{23}$.

Table 2 shows the calculated $G$ values for the different dyePGD dosimeters prepared. The $G$ values were observed to be in a continuously decreasing trend when the absorbed dose increased from 7000 to $28000 \mathrm{kGy}$ for all different dye-PGD dosimeters.

The decrease in $\mathrm{G}$ values may have been related to the situation as the dye concentration decreases, where the dose absorbed increases (Figure 1) ${ }^{21}$.

\section{DISCUSSION}

Gamma irradiation is the most popular form of radiation sterilization and is used when materials are sensitive to the high temperature of autoclaving but are compatible with ionizing radiation ${ }^{22}$. Exposure is achieved when the packages are transported around an exposed ${ }^{60} \mathrm{Co}$ source for a defined period of time.

The European standard (EN 522) for the use of gamma rays on medical devices at a minimum dose of $25 \mathrm{kGy}$ ensures the sterility assurance level of $10^{-6}$. The international and European standards for the validation and routine control of medical device sterilization using ionizing radiation requires that a sterilization dose of $25 \mathrm{kGy}$ should be effective ${ }^{23}$.

Table 1 . The calculated $k, D_{0.5}, D_{0.9}$ and $D_{0.99}$ values for the different dye-polymer gel dosimeters prepared

\begin{tabular}{|l|l|l|l|}
\hline & CV-PGD & MB-PGD & MO-PGD \\
\hline $\mathrm{k} \times 10^{6}\left(\mathrm{~Gy}^{-1}\right)$ & 4.00 & 1.00 & 4.00 \\
\hline $\mathrm{D}_{0.5}(\mathrm{~Gy})$ & 0.173 & 0.693 & 0.173 \\
\hline $\mathrm{D}_{0.9}(\mathrm{~Gy})$ & 0.576 & 2.303 & 0.576 \\
\hline $\mathrm{D}_{0.99}(\mathrm{~Gy})$ & 1.151 & 4.605 & 1.151 \\
\hline $\begin{array}{l}\text { PGD: Polymer gel dosimeter, CV: Crystal violet, MB: Methylene blue, M0: Methyl } \\
\text { orange }\end{array}$
\end{tabular}

Table 2. The calculated $\mathbf{G}$ values for the different dye-polymer gel dosimeters prepared

\begin{tabular}{|l|l|l|l|}
\hline \multirow{2}{*}{$\begin{array}{l}\text { Absorbed dose } \\
\text { (Gy) }\end{array}$} & G values (molecules/100 eV) \\
\cline { 2 - 4 } & CV-PGD & MB-PGD & MO-PGD \\
\hline 7000 & 1.87 & 2.26 & 0.27 \\
\hline 14000 & 1.04 & 1.24 & 0.17 \\
\hline 21000 & 0.76 & 0.92 & 0.34 \\
\hline 28000 & 0.62 & 0.74 & 0.14 \\
\hline $\begin{array}{l}\mid l \\
\text { PGD: Polymer gel dosimeter, CV: Crystal violet, MB: Methylene blue, MO: Methyl } \\
\text { orange }\end{array}$
\end{tabular}


PGD dosimeters were irradiated in a range from $7 \mathrm{kGy}$ to $28 \mathrm{kGy}$. As shown in Figure 2, as the radiation dose increases, the color of the various PGD dosimeters is bleached. Even at a sterilization dose of $25 \mathrm{kGy}$, the dark blue color of the nonirradiated CV-PGD became almost colorless.

Three different PGD dosimeters containing different dyes (CV-PGD, MB-PGD and MO-PGD) were analyzed at their own absorbance peaks of 592, 664 and $462 \mathrm{~nm}$ wavelengths by an UV spectrophotometer. Figure 3 shows the calibration lines for $\mathrm{CV}, \mathrm{MB}$ and $\mathrm{MO}$, respectively. According to equation 1, the dose response of three different $P G D$ dosimeters are summarized in Table 3 and Figure 4.

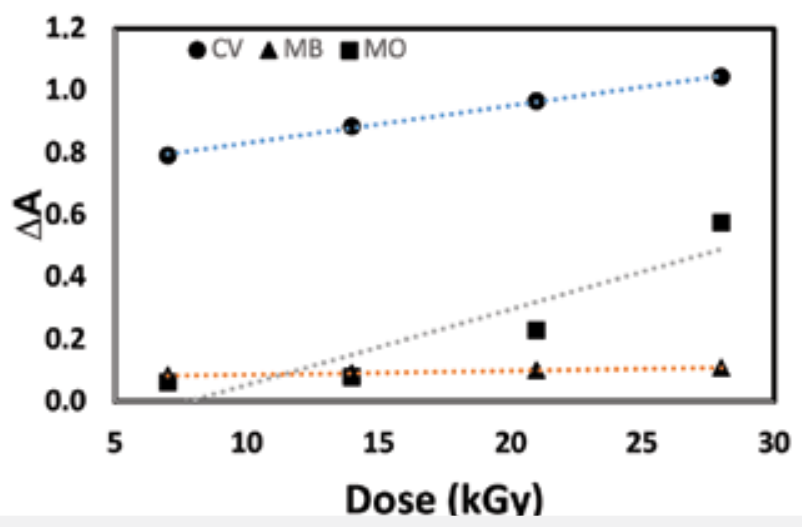

Figure 1. Linear dose response of the three different polimer jel dosimeters

$\triangle A$ : Relative absorbance, CV: Crystal violet, MB: Methylene blue, MO: Methyl orange

\section{Study Limitations}

The findings of this study should be evaluated considering some limitations. There is very little prior research on our specific topic, and we had to develop research typology. DyePGD dosimeters are suitable for use in monitoring various high dose radiation-processing applications and the usage in medical devices, pharmaceutical products and biological tissues should be supported with new studies for further development in this area.

\section{CONCLUSION}

Sterilization of medical devices is very important in medical sector. Many different health risks arise in the absence of sterilization for health care products and surgical materials. To keep patients safe during the surgical process, medical conditions are extremely important during surgery. Thus medical sterilization is vitally important. Radiation sterilization has been widely used worldwide for the sterilization of health care products.

In this study, a novel PGD based on ITA, AAm, gelatin and different dyes (MB, MO and CV) was prepared. The sample spectrums of the prepared PGD dosimeters underwent a change following gamma irradiation, and bleaching of the blue gel color increased with the radiation dose. Even at the normal sterilization dose for medical devices (25kGy), the dark blue color of the nonirradiated CV-PGD became almost colorless. The response of non-irradiated and irradiated PGD dosimeters was stable during a storage period of 60 days. Therefore, the prepared dye-PGD dosimeters are suitable for use in monitoring various high dose radiation-processing applications, which can be useful for many medical devices, pharmaceutical products and biological tissues.

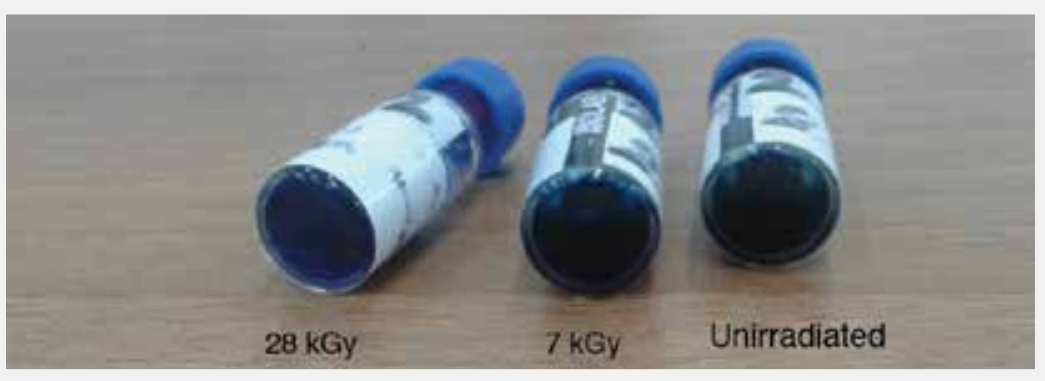

Figure 2. The resulting color change in methylene blue-polymer gel dosimeter following irradiation

Table 3. The dose response of the three different polimer jel dosimeters prepared

\begin{tabular}{|c|c|c|c|c|c|}
\hline Dosimeter name & Ao (non-irradiated) (absorbance) & 7 kGy $A_{i}$ (abs) & 14 kGy $A_{i}$ (abs) & $21 \mathrm{kGy} A_{i}$ (abs) & $28 \mathrm{kGy} \mathrm{A}_{\mathrm{i}}$ (abs) \\
\hline CV-PGD & 1.111 & 0.318 & 0.226 & 0.144 & 0.065 \\
\hline MB-PGD & 0.941 & 0.858 & 0.850 & 0.840 & 0.832 \\
\hline
\end{tabular}

PGD: Polymer gel dosimeter, CV: Crystal violet, MB: Methylene blue, MO: Methyl orange, abs: Absorbance, Ao: Non-irradiated sample, $A_{\mathrm{i}}$ : Irradiated sample 


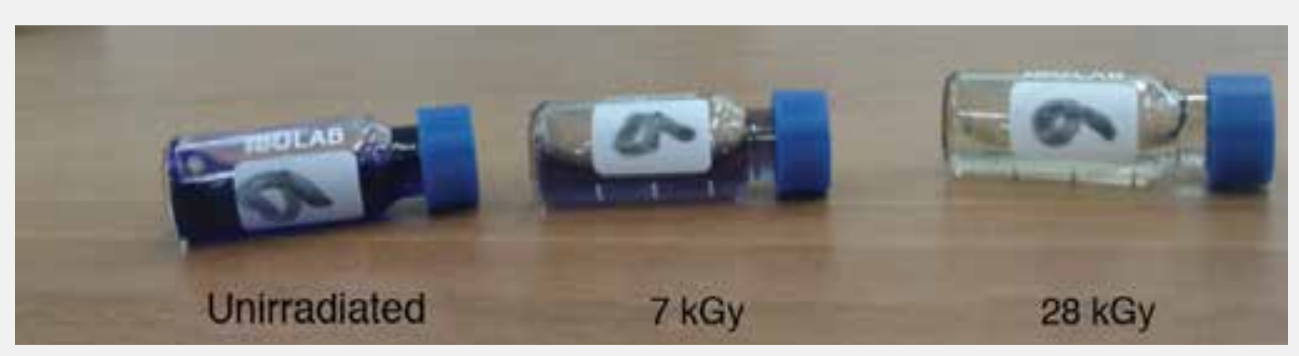

Figure 3. The resulting color change in crystal violet-polymer gel dosimeter following irradiation

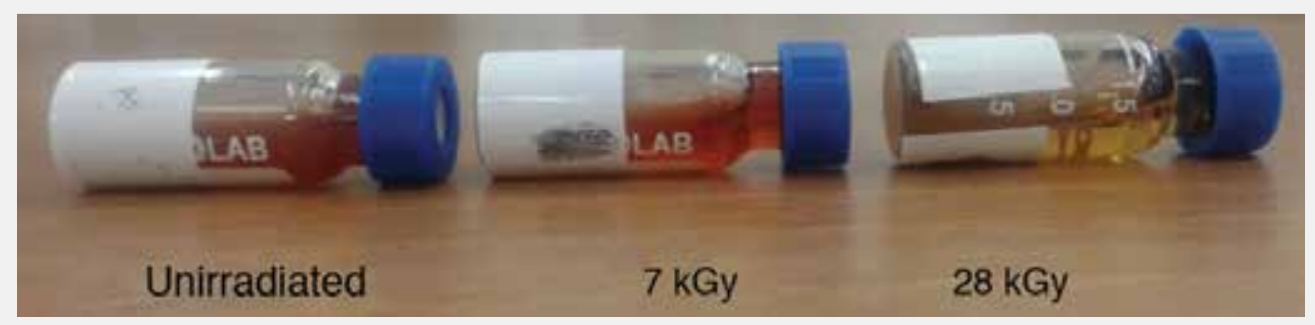

Figure 4. The resulting color change in methyl orange-polymer gel dosimeter upon irradiation

\section{Ethics}

Ethics Committee Approval and Informed Consent: All applicable international and national ethical guidelines were followed. No animal or human subject requiring ethics committee approval was included in the study.

Peer-review: Externally peer-reviewed.

\section{Authorship Contributions}

Concept: B.T., Design: B.T., S.S., Data Collection or Processing: B.T., Analysis or Interpretation: B.T., S.S., Literature Search: B.T., S.S., Writing: B.T., S.S.

Conflict of Interest: No conflict of interest was declared by the authors.

Financial Disclosure: The authors acknowledge Tekirdağ Namık Kemal University Scientific Research Project NKUBAP.06. GA.18.150) for funding.

\section{References}

1. Leurage $\mathrm{S}$, Simmons A: Sterilisation of Biomaterials and Medical Devices. Woodhead Publishing: Cambridge, 2012.

2. Rutala WA, Weber DJ. Disinfection and Sterilization in Health Care Facilities: An Overview and Current Issues. Infect Dis Clin North Am. 2016;30:609-37.

3. Jansen B. Bacterial adhesion to medical polymers--use of radiation techniques for the prevention of materials-associated infections. Clin Mater. 1990;6:65-74.

4. Brinston RM, Wilson BK. Converting to gamma-radiation sterilization: an overview for medical device manufacturers. Med Device Technol. 1993;4:18-22.
5. Abd M, Radwan El-N, El-Monaem A, Bashandy, El-Ghamry A, Fouda A. Evaluation and microbiological investigations of radiation sterilization of disposable blood tubing set. Int J Adv Res Biol Sci. 2016;3:17-26.

6. Parwaie W, Geraily G, Shirazi A, Mehri-Kakavand G, Farzin M. Evaluation of ferrous benzoic methylthymol-blue gel as a dosimeter via magnetic resonance imaging. Phys Med. 2020;80:47-56.

7. Baldock C. Historical overview of the development of gel dosimetry: personal perspective. J Phys Conf Ser. 2006;56:14-22.

8. Khan M, Heilemann G, Lechner W, Georg D, Berg AG. Basic Properties of a New Polymer Gel for 3D-Dosimetry at High Dose-Rates Typical for FFF Irradiation Based on Dithiothreitol and Methacrylic Acid (MAGADIT): Sensitivity, Range, Reproducibility, Accuracy, Dose Rate Effect and Impact of Oxygen Scavenger. Polymers (Basel). 2019;11:1717.

9. Fuse $H$, Oyama $S$, Yasue $K$, Ito $S$, Sato $T$, Fujisaki $T$, et al. Design and characteristics of an agar additive polymer gel dosimeter. Appl Radiat Isot. 2019;151:62-6.

10. Rashidi A, Abtahi SMM, Saeedzadeh E, Akbari ME. A new formulation of polymer gel dosimeter with reduced toxicity: Dosimetric characteristics and radiological properties. Z Med Phys. 2020;30:185-93.

11. Rabaeh $K A$, Saion $E$, Omer $M$, Shahrim I, Alrahman AA, Hussain $M$. Enhancements in 3D dosimetry measurement using polymer gel and MRI. Radiation Measurements. 2008;43:1377-82.

12. Chacon $D$, Strumia $M$, Valente $M$, Mattea F. Effect of inorganic salts and matrix crosslinking on the dose response of polymer gel dosimeters based on acrylamide. Radiat Meas. 2018;117:7-18.

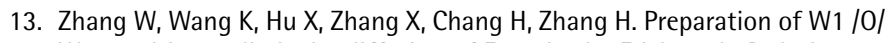
W2 emulsion to limit the diffusion of $\mathrm{Fe} 3+$ in the Fricke gel 3D dosimeter. Polym Adv Technol. 2020;31:2127-35.

14. Mattea F, Chacón D, Vedelago J, Valente M, Strumia MC. Polymer gel dosimeter based on itaconic acid. Appl Radiat Isot. 2015;105:98-104.

15. Senden RJ, De Jean P, McAuley KB, Schreiner U. Polymer gel dosimeters with reduced toxicity: a preliminary investigation of the NMR and optical dose-response using different monomers. Phys Med Biol. 2006;51:3301-14.

16. Venning AJ, Hill B, Brindha $S$, Healy BJ, Baldock C. Investigation of the 
PAGAT polymer gel dosimeter using magnetic resonance imaging. Phys Med Biol. 2005;50:3875-88.

17. Tasdelen B, Erdogan S, Bekar B. Radiation synthesis and characterization of chitosan/hyraluronic acid/hydroxyapatite hydrogels: Drug uptake and drug delivery systems, Materials Today: Proceedings.2018;5,15990-15997.

18. Xue J, Wang J. Radiolysis of pentachlorophenol (PCP) in aqueous solution by gamma radiation. J Environ Sci (China). 2008;20:1153-7.

19. Ismail $M$, Khan HM, Sayed $M$, Cooper WJ. Advanced oxidation for the treatment of chlorpyrifos in aqueous solution. Chemosphere. 2013;93:64551.
20. Sun Z, AbAziz A, Yusof AK. Radiation-induced noncancer risks in interventional cardiology: optimisation of procedures and staff and patient dose reduction. Biomed Res Int. 2013;2013:976962.

21. Basfar $A A$, Khan HM, Al-Shahrani AA, Cooper WJ. Radiation induced decomposition of methyl tert-butyl ether in water in presence of chloroform: kinetic modelling. Water Res. 2005;39:2085-95.

22. Simmons A. Future trends for the sterilisation of biomaterials and medical devices. Sterilisation of Biomaterials and Medical Devices. 2012;310-320.

23. International Atomic Energy Agency, Trends in radiation sterilization of health care products, Vienna, 2008. https://www-pub.iaea.org/MTCD/ Publications/PDF/Pub1313_web.pdf Accessed 10 March 2021. 